\title{
FORMY KOBIECE] PAMIĘCI O DOŚWIADCZENIU WOJENNYM UTRWALONE W LITERATURZE PIĘKNE] W BOŚNI I HERCEGOWINIE
}

\section{ANNA MODELSKA-KWAŚNIOWSKA}

\section{TYPES OF FEMALE'S MEMORY OF THE WAR EXPERIENCE FIXED IN THE LITERATURE OF BOSNIA AND HERZECOVINA}

\begin{abstract}
The memory of the experience of the war in Bosnia and Herzegovina (1992-1995) is a phenomenon strongly present in contemporary literature. The subject of my interest is the specificity of women's memory, which is characterized primarily by anti-war and anti-military discourse, which is a fundamental feature of women's writing about the war, breaking the patriarchal code (statement by Swietlana Aleksijewicz). A notable feature of women's creativity in $\mathrm{BiH}$ is that the memory of war is revealed in it in two fundamentally different ways: 1 . a direct description of war experiences and experiences is usually visible in the texts of the authors of the older generation (Alma Lazarevska; Jasmina Musabegović, Jasna Šamić, Nermina Kurspahić); 2. the indirect presence of the memory of the war in works whose subject matter and time of action is not directly related to the experience of war, but the war, in an unintended way, appears in the background of the story, is typical of the authors of the middle and younger generation (Šejla Šehabovic, Lejla Kalamujić, Tanja Stupar-Trifunović).
\end{abstract}

KEY WORDS the war in Bosnia and Herzegovina in literature; women's literature; Alma Lazarevska; Jasmina Musabegović; Jasna Šamić; Šejla Šehabović; Lejla Kalamujić; Tanja Stupar-Trifunović

CONTACT Uniwersytet Opolski, Wydziat Filologiczny, Instytut Nauk o Literaturze; amodelska@uni.opole.pl 
Wszystko, co wiemy o wojnie powiedziat nam „męski głos”. Wszyscy tkwimy w niewoli „męskich" wyobrażeń $i$ „męskich” doznań wojennych. „Męskich” stów. Kobiety milczą. (...) Milcza nawet te, które byty na wojnie. Jeśli nagle zaczynaja mówić, to opowiadaja nie o swojej wojnie, ale o cudzej. Innej. Dostosowuja się do męskiego szablonu. (...) Wielokrotnie zadawalam sobie pytanie: Dlaczego tak jest? Dlaczego kobiety wywalczyły sobie miejsce w świecie, dawniej wyłącznie męskim, a nie potrafity obronić własnej historii? Swoich własnych uczuć i czynów? Nie uwierzyły samym sobie. Przed nami ukryty jest cały świat. Ich wojna pozostała nieznana... chciałabym napisać historię tej wojny. Historię kobieca.

(Aleksijewicz 2015: 9-10)

Według Ewy Kraskowskiej po 1989 roku na południu postkomunistycznej Europy kluczowym doświadczeniem nie był upadek komunizmu, ale rozpad multietnicznego państwa jugosłowiańskiego i powstanie - w efekcie konfliktów wojennych - nowych państw narodowych (Kraskowska 2005: 19). Znamienne, że przy podpisaniu traktatu pokojowego w Dayton w grudniu 1995 roku, kończącego trzyipółletni konflikt zbrojny w Bośni i Hercegowinie, nie było ani jednej obywatelki tego kraju. Wykluczenie kobiet w tej oficjalnej sytuacji potwierdza stale obecną tak w życiu publicznym, jak i prywatnym mizoginię, będącą - w pewnym tylko stopniu - dziedzictwem wojny (Zabilježene 2014: 228). Nieobecność kobiet w życiu publicznym, mająca swe źródło w słabym zadomowieniu kobiet w historii (Ubertowska 2015: 7), w tradycyjnych bałkańskich społeczeństwach wiąże się dodatkowo z konsekwentnym niedostrzeganiem ich w życiu publicznym. Pisała o tym m.in. Lada Stevanović, upominając się o przerwanie towarzyszącego kobietom na Bałkanach milczenia, będącego efektem nieustających wysiłków zmierzających niedopuszczania kobiet do głosu, a także - z drugiej strony - z konsekwentnego zaniedbywania badań nad ich rolą w historii (Stevanović 2011: 124).

Gwałtowny rozpad Jugosławii i wojna domowa w Bośni i Hercegowinie latach 1992-1995 powodując traumę kulturową ${ }^{1}$ (Sztompka 2000), wymusiły zmiany, w tym - społeczną aktywizację kobiet, które w nowych okolicznościach podejmowały konkretne działania. W warunkach wojennych wyraźnie odżył ruch feministyczny, ściśle związany z ruchem antywojennym oraz działalnością na rzecz pokoju (Đurić 2011: 264). Według Magdaleny Koch problematyzacja kwestii płci, którą obserwujemy w latach dziewięćdziesiątych ubiegłego stulecia, jest zjawiskiem typowym dla okresu konfliktów zbrojnych (Koch 2011: 130). Wzrost znaczenia ideologii nacjonalistycznych wiąże się z uznaniem odpowiedzialności kobiet za biologiczne trwanie i wpływa na stopniowe ograniczanie ich praw reprodukcyjnych; rola kobiety była w czasie wojny z góry określona: jako podwójnej Innej (płciowo i narodowo). W związku z tym afirmowano jej biologiczną funkcję Matki Narodu (odnawianie narodu poprzez macierzyństwo, powiązane z ograniczeniem kobiety do przestrzeni prywatnej - domowej), poddając równocześnie strategiom kolektywizacji oraz nacjonalizacji i w efekcie seksualnej przemocy wojennej (Omeragić 2013).

1 Według Piotra Sztompki trauma kulturowa jest najważniejszym typem traumy społecznej, ze względu na to, że trwa dłużej niż inne jej rodzaje (demograficzna, strukturalna). Jest przechowywana w pamięci zbiorowej lub uśpiona w zbiorowej nieświadomości, by w sprzyjających okolicznościach się ujawnić, jak to miało na przykład miejsce w pierwszej połowie lat dziewięćdziesiątych w rozpadającej się Jugosławii. Socjolog wyjaśnia to w następujący sposób: „(...) zakorzenione w gwałtownych, bolesnych zdarzeniach w zamierzchłej przeszłości, nagle wybuchające ponownie w formie nienawiści międzygrupowej, konfliktów etnicznych, a nawet wojen" (Sztompka 2000: 29). 
Jasmina Husanović przywołuje trzy strategie radzenia sobie ze świadczeniem o traumie, które funkcjonują w Bośni i na terenach byłej Jugosławii:

1. mitologizacja (mitologizacija) - gdy traumatyczne doświadczenie przetwarzane jest w narrację, w której dominuje motyw przezwyciężenia cierpienia i wyjścia zwycięsko z sytuacji wojennej;

2. medykalizacja (medikalizacija) - świadczenie o traumie postrzegane jest jako syndrom choroby PTSD (zespół stresu pourazowego), stanowi zatem przedmiot badań psychiatrów, co powoduje, że polityczny wymiar sprawy ulega stępieniu (gdy człowiek zostanie wyleczony, znów może funkcjonować społecznie);

3. wymazywanie (ǐ̌čezavanje) - odsuwanie świadomości traumy i chęci jej zgłębienia, co prowadzi do poddawania w wątpliwość wiarygodności ofiar i tych, którzy przeżyli.

Niestety żadna z tych strategii nie zakłada realnego zmierzenia się z traumą, jej przepracowania, które umożliwiłoby przejście do kolejnego etapu normalnego funkcjonowania w rzeczywistości powojennej. Bośniacka eseistka ilustruje swoje tezy realnymi przykładami z życia społecznego i podkreśla, że jest to zjawisko niepożądane i szkodliwe nie tylko z perspektywy jednostki, ale także z perspektywy zbiorowości i z punktu widzenia interesu publicznego. Jednocześnie badaczka podkreśla rolę, jaką we współczesnym procesie świadczenia o traumie odgrywa sztuka, w tym literatura tworzona przez kobiety (Husanović 2010: 58-64).

Pamięć o doświadczeniu wojny w Bośni i Hercegowinie jest zjawiskiem silnie obecnym we współczesnym piśmiennictwie, bogatym w literackie reprezentacje pamięci indywidualnej (Erll 2018: 130), które jednak w znacznym stopniu są osadzone w bohaterskim paradygmacie kulturowym. Enver Kazaz pisał o tym zjawisku, wskazując na jego długie tradycje w kulturze bośniackiej: „Od epskih pjesama i romantičarskih epova, preko heroja Prvog svjetskog rata, a onda i Drugog svjetskog rata društveno pamćenje na južnoslovenskom kulturnom prostoru je ne samo herojskocentrično nego i muškocentrično, te patriocentrično kodirano. (...) Herojskocentričnost naracije o posljednjim ratovima (...) nasljeđe je duge tradicije epski kodiranih južnoslavenskih nacionalnih kultura, pri čemu je titanska figura heroja sami centar povijesne memorije" (Kazaz 2011: 331).

W niniejszym tekście przedmiotem zainteresowania jest specyfika kobiecej pamięci, którą charakteryzuje przede wszystkim dyskurs antywojenny i antymilitarystyczny, a tym samym dążenie do przełamywania kodu patriarchalnego (Aleksijewicz 2015). Jak zauważyła Svetlana Slapšak „[w]ojna wpłynęła na pisarki w sposób, w jaki nie mógł tego zrobić feminizm akademicki - zainspirowała je do stawiania czoła zbiorowemu cierpieniu i nowym straszliwym realiom życia" (Slapšak 2005: 156-157).

Mimo niekorzystnej społecznej atmosfery faktem jest, że po 1990 roku w Bośni i Hercegowinie obserwujemy coraz wyraźniejszą reprezentację kobiet w literaturze, a poszczególne pisarki wybierają różne strategie ujmowania kobiecej podmiotowości, co znalazło wyraz np. w określeniu współczesnej kobiecej poezji i prozy w przywoływanej już publikacji Zabilježene jako književnost razlika, charakteryzującą się przede wszystkim wyraźną obecnością pierwiastka intertekstualnego oraz preferowaniem krótkich form: opowiadania, ewentualnie - rzadziej - 
krótkiej powieści w obrębie prozy, a także - choć w mniejszym stopniu - obecnością poezji, co jest sposobem na odrzucenie wielkiej opowieści (otpor velikoj priči) (Zabilježene 2014: 255).

Znamienną cechą twórczości kobiecej w Bośni i Hercegowinie jest to, że pamięć o wojnie ujawnia się w niej na dwa zasadniczo odmienne sposoby:

I. bezpośredni opis przeżyć i doświadczeń wojennych uwidacznia się zazwyczaj w tekstach autorek starszego pokolenia, których pisarstwo, naznaczone rysem autobiografizmu, odzwierciedla cywilne doświadczenie wojny, wpisując się tym samym w nurt mikrohistorii;

II. pośrednia obecność pamięci o wojnie w utworach, których tematyka i czas akcji nie pozostaje w bezpośrednim związku z doświadczeniem wojennym, niemniej wojna, niejako $\mathrm{w}$ niezamierzony sposób, pojawia się w tle opowieści, jest typowa dla autorek średniego i młodszego pokolenia.

\section{$1 /$ KOBIECA TWÓRCZOŚĆ LITERACKA ODNOSZĄCA SIĘ DO PRZEŻYĆ I DOŚWIADCZEŃ WOJENNYCH W SPOSÓB BEZPOŚREDNI}

W obiegu czytelniczym funkcjonuje i cieszy się popularnością twórczość autorek piszących w sposób tradycyjny, dla której znamienna jest ideologizacja wojny, znajdująca wyraz np. w obecności figury Bośniackiej Matki² , typowa zwłaszcza dla literatury tematyzującej doświadczenie ludobójstwa w Srebrenicy. Nurt ten reprezentują m.in. Nermina Kurspahić (ur. 1956) (Iščzavanje plavih jahača, 1996) oraz Nura Bazdulj-Hubijar (ur. 1951) (Ljubav je sihirbaz, babo, 1994; Kad je bio juli, 2005; Baš mi je žao, 1999), utrwalając specyficzny dla narracji wojennych dyskurs ciała (ciało staje się nośnikiem pamięci kulturowej, akt zapamiętywania dokonuje się poprzez „zapisywanie” traumatycznych doświadczeń w ciałach ofiar) powiązany z ideą męczeństwa (szahadatu). Srebrenickie teksty kobiet, nacechowane religijnością, ideologią męczeństwa oraz dyskursem ciała, zasadzające się na tradycyjnym podziale ról kulturowych uznane zostały za szczególnie ważne dla boszniackiej tożsamości budowanej na poczuciu bycia ofiarą (Jawoszek 2014: 144). Uznana przez krytykę za nieudaną popularna powieść Nerminy Kurspahić Ǐ̌čezavanje plavih jahača ukazywała się w odcinkach w prasie w oblężonym Sarajewie. Jest to według Jawoszek: „(...) wzorcowy przykład użycia literatury w procesie definiowania tożsamości narodowej poprzez opowieść o traumie" (Jawoszek 2014: 27).

Z typowym dla zorientowanej tradycjonalistycznie prozy Boszniaczek wzorcem Bośniackiej Matki polemizuje już na poziomie tytułu swojego debiutanckiego tomu poetyckiego Neće biti djece za rat (2017) Dijala Hasanbegović. Wskazując na zwrot w stronę przeszłości i motyw wojennej traumy, zawiera on także deklarację, stanowiącą jednoznaczne odrzucenie

2 Konstrukcja Bośniackiej Matki pozostaje w niekwestionowanym związku z mocno zakorzenioną w polskiej kulturze figurą kulturową Matki Polki, związaną ściśle z historią polskiej walki o niepodległość („Matka-Polka to (...) przede wszystkim figura, konstrukcja stworzona na użytek historii, pomnikowa postać poświęcająca siebie i swe dzieci dla dobra ojczyzny” - Kowalczyk 2010: 51; „Matka-Polka to mit przesiąknięty antykobiecą ideologią bogoojczyźnianą, postać na usługach systemu patriarchalnego, strażniczka tradycyjnych wartości, bogini domowego ogniska (...). Jest postacią pozbawioną własnych uczuć, własnego ciała, własnego głosu. (...) Przeciwieństwem Matki-Polki były (...) feministki, strącające mit z cokołu, pytające o jego znaczenie, odsłaniające to, co zostało przez niego wyparte" - Kowalczyk 2010: 63). 
konstruktu kulturowego Bośniackiej Matki, opisującego kobietę we właściwy dla patriarchatu sposób: „wywyższenie przez obniżenie” (Iwasiów 2008: 126). Jest to zdecydowane zanegowanie ideologii nacjonalistycznych i militarystycznych.

Typowym dla literatury w regionie zjawiskiem rozwijającym się w czasie wojny lub wkrótce po zakończeniu konfliktu jest žensko ratno pismo3 (kobiece pisanie o wojnie), reprezentowane przez Feridę Duraković (ur. 1957), Almę Lazarevską (ur. 1957), oraz Jasnę Šamić (Kazaz 2004a: 108; Hawkesworth 2000: 263). Jest to nurt literatury zaangażowanej politycznie i ideologicznie, dekonstruujący ideologię zbrodni. Žensko ratno pismo charakteryzuje pisanie o traumie wojennej przy jednoczesnym odrzuceniu etosu heroicznego w odniesieniu do bohatera męskiego oraz kobiecej figury ofiary.

Opowiadania Almy Lazarevskiej zebrane w tomie Smrt u Muzeju moderne umjetnosti (1996) wyróżniają się specyficzną konstrukcją czasu i przestrzeni, metaforyką osnutą wokół domu i ciała oraz narracją podporządkowaną indywidualnej pamięci bohaterki, oddającą w finezyjny sposób klaustrofobiczną atmosferę życia w odciętym od świata mieście. Poprzez często występujący w literaturze kobiet o tematyce wojennej motyw rodziny pozostającej w pewnym odosobnieniu, izolacji, bo tylko tak mogącej znaleźć schronienie przed zewnętrznym zagrożeniem, wpisuje się w nurt mikrohistorii. Reprezentacja doświadczeń wojennych, często niemożliwa do zwerbalizowania, wiąże się z obecnością dyskursu ciała, co nie jest zresztą w literaturze bośniackiej zjawiskiem zupełnie nowym. Reprezentująca kobieca powieść nowo historyczną Jasmina Musabegović w swoich powieściach Snopis (1980) i Skretnice (1986) wprowadziła podobne rozwiązania. Przeżycia bohaterek były tam relacjonowane przez pryzmat doświadczeń cielesnych; dyskurs ciała służył ukazaniu tego, co jest niemożliwe do zwerbalizowania, ze szczególnym uwzględnieniem niemożliwości językowej reprezentacji traumatycznych doświadczeń wojennych (Moranjak-Bamburać 2005: 198-211). Należy również zauważyć, że zabiegi te służą dowartościowaniu cielesności, podobnie zresztą rzecz się ma z przestrzenią domową, tradycyjnie przypisywaną w kulturze kobiecie.

Forma gatunkowa - krótkie opowiadanie - którą posługuje się Lazarevska, odzwierciedla rozczłonkowanie opisywanego świata i tym samym niemożność ujęcia go w jedną spójną całość, wielką opowieść. Zbiór został opublikowany w rok po zakończeniu wojny w Bośni, a temat

3 Žensko ratno pismo jest kontaminacją dwóch pojęć: ratno pismo i žensko pismo. Ratno pismo [wojenne pisanie] oznacza twórczość tematyzującą doświadczenie wojenne, choć - co podkreśla wybitny bośniacki badacz literatury Enver Kazaz - termin ten odnosi się wyłącznie do tematyki twórczości pisarzy umieszczanych w tym nurcie, przy czym pominięciu ulega jej nasycenie ideologiczne (aspekt antywojenny). W istocie należałoby bowiem mówić o zjawisku anti-ratnog pisma. Używanie terminu ratno pismo jest w tym przypadku formą skrótu myślowego. Zasadniczą cechą pisania o wojnie z typową dlań poetyką zaświadczania jest dekonstrukcja wielkich narracji, w imię których toczona jest walka, co prowadzi do dowartościowania indywidualnej perspektywy, skupienia na codziennych rytuałach, na świecie przeżyć wewnętrznych, ale także na aspekcie cielesności bohaterów dotkniętych wojną (Kazaz 2004b).

Termin žensko pismo [pisarstwo kobiece] ma charakter niejednoznaczny, używany bywa w sposób dowolny na oznaczenie literatury tworzonej przez kobiety (ženska književnost [literatura kobieca], žensko stvaralaštvo [twórczość kobieca], wyodrębnionej wyłącznie na podstawie kryterium płciowego (Lukić 2003). Nieporozumienia terminologiczne rozwiewa Barbara Czapik-Lityńska pisząc, że: [ž]ensko pismo inspirowane przez pewien czas écriture féminine wyróżnia się dużą wrażliwością na wszelkie uwikłania psychologiczne i społeczne kobiety, jej pozycje / funkcję w społeczeństwie $i$ kulturze. Penetrując szerokie spektrum spraw (nie tylko) kobiecych, autorki zbliżyty się do krytyki feministycznej, dekonstrukcji etycznej, antropologii kulturowej, czy nowoczesnej socjologii zorientowanej na relacje między człowiekiem, kulturą a władzą (Czapik-Lityńska 2009: 166-167). 
oblężenia Sarajewa stał się trwałą obsesją pisarki. Poczucie ważności tego kluczowego doświadczenia i swoista niemożność uwolnienia się od pamięci o oblężeniu, naznaczona poczuciem odpowiedzialności elit intelektualnych za wojnę, nadaje jej prozie rys autobiografizmu, co wzmacnia jeszcze pierwszoosobowa narracja dominująca w zbiorze. Narrację charakteryzuje przede wszystkim budowanie opowieści w sposób dygresyjny, na zasadzie skojarzeniowej. Wspomaga ją konstrukcja czasu podporządkowana pamięci narratorki, co sprawia, że czas wojny i czas pokoju swobodnie się przeplatają. Kobieca narratorka w sposób precyzyjny, wręcz drobiazgowy, wykorzystując metafory domu, mleka, wody i ciała, opisuje intymną przestrzeń, w którą stopniowo wdziera się wojna.

Nasycenie pierwiastkiem autobiografizmu jest znamienną cechąženskog ratnog pisma; opis świata skażonego wojną jest w twórczości autorek tego nurtu formą osobistej prawdy, potwierdzonej własnym przeżyciem. Wpisuje się tutaj także pisząca po bośniacku i francusku Jasna Šamić. Wśród jej bogatej i zróżnicowanej artystycznie twórczości (wiersze, eseje, powieści, opowiadania, sztuki teatralne, reżyseruje filmy, przekłady) szczególną uwagę zwraca Mraz i pepeo (1997) - poświęcona ojcu, jedna z najciekawszych powieści, która w sposób pośredni dotyka tematyki wojennej, przez Envera Kazaza umieszczona w nurcie novi ratni roman (nowa powieść wojenna) (Kazaz 2004a: 153), realizująca poetykę zaświadczania (poetika svjedočenja). Charakter autobiograficzny ma również Carstvo sjenki (2007), która to powieść tematycznie dotyczy relacji matka-córka.

Ferida Duraković, obecna w życiu literackim Bośni i Hercegowiny od roku 1977, w późniejszych zbiorach poetyckich: Srce tame (1994), Locus minoris - sklonost Bosni kao melanholiji (2007), pokazała się jako poetka moralnie zaangażowana, przemawiająca z perspektywy uwzględniającej płeć i odrzucająca dominującą heroiczną narrację i militarystyczny dyskurs. Podmiot liryczny w jej wierszach mówi we własnym, kobiecym imieniu i w imieniu innych ofiar, reprezentuje cywilne doświadczenie wojny, staje po stronie krzywdzonych i uciskanych, przyjmując pozycję outsidera i sprzeciwiając się wszelkiej niesprawiedliwości, doświadcza poczucia winy wynikającego z etycznej odpowiedzialności. Ważny motyw w poezji Duraković stanowi ojczyzna, mająca wymiar osobisty, intymny, nie utożsamiana z państwem czy narodem, nie będąca konstruktem ideologicznym. Tom Locus minoris ma formę dziennika rejestrującego zapisy z wojennej i powojennej codzienności, co można odczytywać jako formę mikrohistorii, pokazującej rzeczywistość z mikroperspektywy, akcentującej zainteresowanie codziennością i życiem „zwykłych ludzi”, będącej „(...) historią doświadczeń, historią uczuć, prywatnych mikroświatów" (Domańska 1999: 58). Wiersze Feridy Duraković można czytać w kontekście feministycznej etyki troski, dominuje w nich poczucie solidarności ze skrzywdzonymi, nie znające jakichkolwiek - etnicznych czy państwowych - granic. Zwraca się w nich w stronę Innych, wykluczonych, skazanych na milczenie.

Pamięć o wojnie w wierszach jednej z ważniejszych bośniackich poetek, jaką jest Bisera Alikadić, autorka kilkunastu zbiorów poetyckich, spośród których pierwszy, Intonacije, ukazał się w roku 1957, natomiast ostatni Žirafa u plamenu, w 2008 roku, jest obecna bardzo wyraźnie, a poetycki opis życia w oblężonym mieście kształtowany jest z perspektywy starzejącej się kobiety zatroskanej o losy matki w podeszłym wieku, która u schyłku życia doświadcza grozy bratobójczej wojny. Zarówno wiersze Alikadić, jak i innych autorek, reprezentujących wszystkie generacje, podejmujące próbę przepracowania wojennej traumy, nie są jedynie wyrazem 
estetyzacji cierpienia i tragedii, ale stanowią formę literackiego upamiętnienia i co za tym idzie upodmiotowienia ofiar (Omeragić 2013).

Znaczącą kwestią jest to, że kobieca pamięć o wojnie w literackich reprezentacjach pomija doświadczenia specyficznie kobiece, mianowicie nie podejmuje prób opisu form przemocy dotykających (głównie) kobiety, przemocy seksualnej. Bez wątpienia jest to skutek silnej społecznej tabuizacji tych problemów, choć - co ciekawe - temat ten zaistniał w kinie, a obraz Jasmili Žbanić Grbavica został dostrzeżony nie tylko w Bośni, ale także poza granicami kraju. W literackiej formie ten szczególnie wstydliwy w patriarchalnej kulturze (zarówno dla pokrzywdzonych jednostek i ich rodzin, jak i dla społeczeństwa jako całości) temat gwałtów wojennych podjęła chorwacka pisarka Slavenka Drakulić w książce Kao da me nema.

Problem ten, zarówno z uwagi na skalę popełnionych przestępstw, jak i ich długofalowe skutki, nie mógł zostać zepchnięty na margines, już w czasie wojny został nagłośniony przez środowiska feministyczne. W 1993 roku podczas Światowej Konferencji Praw Człowieka w Wiedniu feministki zwróciły na tę kwestię uwagę europejskiej opinii publicznej (Hajdarewicz 2012). Zasadniczą trudnością i przeszkodą było milczenie ofiar, które powoli i bardzo niechętnie, z głębokim lękiem przełamywały barierę wstydu. Proces ten wspomagała i umożliwiała intensywna działalność organizacji i stowarzyszeń kobiecych tak w Serbii i Chorwacji, jak i w Bośni (np. Centar za ženske studije, Žene Srebrenice, Udruženje Žene žrtve rata, Gender Centar Federacije Bosne i Hercegovine, Centar za žene Rosa - Centar za žene žrtve rata, prowadzących szeroko zakrojoną działalność edukacyjną i wydawniczą. ${ }^{4}$

W Kao da me nema Drakulić skupiła traumatyczne doświadczenia wielu Bośniaczek (głównie Muzułmanek) w historii młodej nauczycielki. Korzystając z konwencji świadectwa i bazując na prawdziwych historiach kobiet pokrzywdzonych w czasie wojny w Bośni, wybrała formę powieściową. Strategia zastosowana przez chorwacką pisarkę znakomicie przystaje do ustaleń Shoshany Felman, wg której wiek XX jest wiekiem świadectwa wykorzystywanego na różne sposoby w rozmaitych działaniach artystycznych i stanowiącego współcześnie ważny sposób kontaktowania się z różnymi rodzajami traumy. Niemniej jednak świadectwo nie potrafi ująć opisywanych wydarzeń w zamkniętej formie, nie prezentuje całościowego zeznania, bo też język, w którym jest przekazane świadectwo, ma charakter procesualny, nie skończony (Felman 2004: 348-349). Slavenka Drakulić wykorzystała formę świadectwa jako temat swojej książki, powieść nie jest jednak świadectwem w ścisłym znaczeniu tego słowa. Wskazuje na to strategia narracyjna zastosowana w utworze: narracja personalna prowadzona z punktu widzenia bohaterki pozwala z jednej strony w sposób niemal bezpośredni ukazać jej sposób odczuwania i myślenia, oddać targające nią, często sprzeczne i gwałtowne, uczucia, z drugiej - umożliwia też silne oddziaływanie na emocje odbiorcy. Od czasu do czasu w opowieść wdziera się jedno bądź dwa zdania sformułowane w pierwszej osobie liczby pojedynczej, jak gdyby narratorka, która uprzednio wysłuchała opowieści S., a potem ją spisywała $\mathrm{w}$ tych wyjątkowych momentach utożsamiała się z nią. To szczególnie dramatyczne momenty w tej historii. Wtedy jak gdyby w nurt głównej historii - opowiadania o S. - wdziera się bezpośrednia opowieść S. W przypadku świadectwa (i narracji pierwszoosobowej) odbiorca odczuwa przede wszystkim współczucie

4 Przykładowe publikacje będące świadectwami pokrzywdzonych kobiet: Ženska strana rata 2007, L. Vušković, Z. Trifunović (edd.), (Beograd: Žene u crnom; Žene žrtve rata 2006, B. Mijić, D. Vojvodić (edd.), (Beograd: Udruženje građana Civis). 
dla ofiary, jednak w efekcie wysłuchania/przeczytania opowieści o S. obok poczucia solidarności wytwarza się też bardzo silne przeświadczenie, że jedynie skutkiem przypadku jest to, że na miejscu Bośniaczki nie znalazł(a) się odbiorca.

Klamrowa kompozycja powieści stanowi ilustrację drogi, jaką przeszła S. w okresie od maja 1992 do marca 1993 roku. Młoda nauczycielka, podobnie jak i inne postacie występujące w bośniackiej rzeczywistości, nie otrzymuje pełnego imienia, a jedynie jego inicjał: S. Używanie inicjałów imion czy nazw miejscowości w Bośni służy zachowaniu anonimowości (jak w przypadku świadectwa), nadaje opisywanej rzeczywistości znamiona uniwersalności, ale też odbiera indywidualność i podkreśla wyobcowanie S., zwłaszcza, że szwedzka położnica, z którą Bośniaczka przebywa w jednym szpitalnym pokoju, a także jej nowo narodzona córeczka mają pełne imiona. One bowiem pochodzą z innego świata.

Kao da me nema to literacki opis wojennego doświadczenia kobiet w Bośni stanowiący bezpośrednie oskarżenie odpowiedzialnych za wywołanie i przebieg konfliktu. Jednocześnie niezmiernie ważną kwestią zasygnalizowaną przez chorwacką pisarkę jest powojenna sytuacja zgwałconych kobiet oraz ich dzieci. Z drugiej zaś strony kreacja bohaterki, która zdobywa się na heroiczny gest przerwania łańcucha nienawiści poprzez zatrzymanie będącego owocem gwałtu dziecka, niesie także przesłanie dla ofiar.

\section{2 / KOBIECA TWÓRCZOŚĆ LITERACKA ODNOSZĄCA SIĘ DO PRZEŻYĆ I DOŚWIADCZEŃ WOJENNYCH W SPOSÓB POŚREDNI}

Pośrednia obecność pamięci o wojnie w utworach, których tematyka i czas akcji nie pozostają w bezpośrednim związku z doświadczeniem wojennym, niemniej wojna, niejako w niezamierzony sposób, pojawia się w tle opowieści, jest typowa dla autorek średniego i młodszego pokolenia, które wprawdzie deklarują chęć odejścia od tematyki wojennej, natomiast w praktyce okazuje się to niemożliwe, ponieważ pamięć o wojnie - zarówno pamięć indywidulna, jak i, częściej, pamięć rodzinna - jest silniejsza. Jak wyjaśnia Šejla Šehabović, wojna jest ciągle obecna w literaturze, a ona sama, choć nigdy nie zamierzała podejmować tego tematu, napisała książkę o wojnie (Koji su pisci... 2013). Należące do średniego pokolenia pisarki, dla którego kluczowym doświadczeniem egzystencjalnym było przeżycie rozpadu Jugosławii oraz wojny domowej w okresie dzieciństwa lub wczesnej młodości reprezentują coraz mocniej obecny w literaturze Bośni i Hercegowiny, zapoczątkowany przez žensko ratno pismo kobiecy, antybohaterski nurt. Twórczość tych autorek Damir Arsenijević określa wspólnym mianem književnost nakon genocida, tworzą ją m. in.: Nermina Omerbegović (ur. 1964), Tatjana Bjelić (ur. 1974), Aleksandra Čvorović (ur. 1976), Šejla Šehabović (ur. 1977), Tanja Stupar Trifunović (ur. 1977), Adisa Bašić (ur. 1979), Lamija Begagić (ur. 1980). Pod względem tematycznym jest to literatura zdominowana przez zagadnienie wojennej traumy, ponadto charakteryzuje ją przede wszystkim wybór małych form (dominuje poezja, a w zakresie prozy - opowiadanie). Odrzucenie wielkiej opowieści (otpor velikoj priči) idzie w parze z poszukiwaniem nowych form i środków wyrazu, ironicznym podważaniem stereotypów i wypowiadaniem się nie tylko w imieniu kobiet, ale i innych mniejszości, w tym seksualnych (Zabilježene 2014: 255-256). 
Šejla Šehabović jako autorka m.in. zbioru opowiadań Priče - ženski rod, množina (Šehabović 2007), który ukazał się w czasie, gdy społeczeństwo Bośni i Hercegowiny wciąż nie uporało się z przeszłością do tego stopnia, że nadal trudno mówić o wojnie i traumach w sposób jawny, a własne bolesne doświadczenia często skazują na marginalizację (Zabilježene 2014:235), zdecydowanie odcina się od bohaterskiego paradygmatu kulturowego i odrzuca naznaczoną etnicznie pamięć o wojnie i jej ofiarach.

W opowiadaniach tych autorka wybiera jedną z typowych kobiecych nisz: twórczość oralną - prezentuje polifonię głosów kobiet i Innych spychanych na margines. Inność / odmienność to zasadnicze cechy bohaterów Šejli Šehabović. Genologiczny wybór autorki jest zgodny z trendami widocznymi w tym nurcie prozy kobiet, jakim jest žensko pismo w Bośni i Hercegowinie od lat 90. XX wieku. Zebrane w tomie utwory układają się w spójną całość pod względem tematyki, typu bohatera oraz strategii narracyjnych. Z całości tekstu wyłania się głos zbiorowy (množina), dominują opowieści kobiet (ženski rod) bądź nielicznych mężczyzn, którzy w pewien sposób nie spełniają kryteriów męskości, są zatem na marginesie życia społecznego - tam, gdzie kobiety. Z sumy wszystkich opowieści wyłania się obraz kobiet funkcjonujących na obrzeżach społeczeństwa, w strategicznych momentach - wbrew tytułowi zbioru - nierzadko wybierających milczenie zamiast przeciwstawienia się mężczyźnie czy odmawiających sobie prawa do mówienia o własnych przeczuciach i intuicjach niepoddających się racjonalizacji. Milczenie odgradza kobiety od życia i skazuje na samotność. Marginalizacja i nieobecność kobiet w życiu społecznym objawiają się często w bezimienności bohaterek.

Tożsamość etniczna czy religijna postaci często pozostaje nieznana albo niedopowiedziana, co jest zabiegiem często stosowanym w pisarstwie kobiet, zwłaszcza w tym jego nurcie, jakim jest žensko pismo, natomiast nie w tradycyinym paradygmacie bohaterskim, gdzie nawet dziecięce ofiary są naznaczone przynależnością do „naszych” albo do „wrogów” (Kazaz 2011:332).

Badaczki problematyki kobiecej w regionie w ślad za Žaraną Papić podkreślają, że zasadniczą i konstruktywną cechą żeńskiej podmiotowości, mocno ugruntowaną historycznie i pozwalającą na przekraczanie granic wyznaczonych przez patriarchat, jest na Bałkanach mobilność (fizyczna, psychiczna, językowa, kulturowa), niosąca ze sobą wielki potencjał antypatriarchalny i pacyfistyczny (Kraskowska 2005: 19; Slapšak 2005: 142-155). Bohaterowie Šejli Šehabović nieustannie zmieniają miejsce pobytu, są bardzo dynamiczni, krążą między różnymi krajami, często także między kontynentami, kulturami i językami, można ich określić wspólnym mianem: niezakorzenieni. Ciągły ruch, niemal przymus przemieszczania się, ma źródło w przeżyciach i doświadczeniach wojennych i wiąże się z przeżywanymi kryzysami tożsamości.

Wojna w Bośni postrzegana jest z kobiecej perspektywy, w centrum uwagi znajduje się kolektywna kobieca pamięć i jest ona rodzajem zwierciadła, w którym odbija się patriarchat, a część bohaterek próbuje przekraczać jego granice. Autorka wielokrotnie sięga po typowo kobiecą symbolikę (woda, krew), balansuje między kulturą bośniacką i amerykańską, dychotomią wyjazdu z Bośni i pozostaniem w kraju, w którym tożsamość zbiorowa jest nadrzędna w stosunku do indywidualnej. Według Alana Pejkovicia narracja wyobcowania, które w życie bohaterów wnosi wojna, jest narracją, w jakiej traci rację bytu linearna męska opowieść, na wartości natomiast zyskuje cykliczna struktura ženskog pisma (Pejković 2008).

Dla bohaterów wojna była kluczowym doświadczeniem życiowym, bo przypadła na okres ich dorastania, poznawania dorosłego życia, co z jednej strony wiąże się z nietypowymi 
wspomnieniami, z drugiej - z dojmującym poczuciem winy ocalałych, które bohaterka opowiadania Odlazim za tri dana porównuje do uczuć, jakich doświadcza górnik wychodzący na powierzchnię po katastrofie, która pochłonęła jego kolegów. Skutki traumy wojennej są długofalowe i wydają się nie mieć końca. „Jednom ćemo zaboraviti rat. Za to jednom ja nemam dovoljno života. Ja želim ići odavdje, negdje gdje ljudi zaboravljaju brže, gdje zaboravljaju sistematično i redom" (Šehabović 2007: 40) stwierdza jedna z bohaterek. Młodzi, którzy w czasie wojny byli nastolatkami (stąd jest to tinejdžerska verzija rata), innego świata już nie pamiętają i dlatego dla nich wojna nigdy się nie skończy, jak konstatuje narratorka w opowiadaniu Voda: „Vama će proći rat. Meni neće, nikad” (Šehabović 2007: 62).

Zbiór opowiadań Šejli Šehabović Priče - ženski rod, množina stanowi istotny głos w dyskusji o położeniu kobiet w powojennej Bośni. Ciekawy artystycznie pomysł zestawienia chóru kobiecych głosów, którym towarzyszą przedstawiciele innych dyskryminowanych grup w społeczeństwie (geje) pozwolił bośniackiej autorce zmierzyć się z aktualnymi i ważnymi społecznie problemami (Husanović 2010: 49). Jest to literatura zaangażowana, o głęboko antywojennej wymowie. Rozwiązania narracyjne, typ i sposób prezentowania bohaterów zbliża prozę Šejli Šehabović do ženskog pisma, a zdecydowanie oddala od dominującego w bośniacko-hercegowińskim dyskursie wojennym paradygmatu bohaterskiego.

Podobnie do prozy Šehabović powieść Tanji Stupar Trifunović Satovi u majčinoj sobi wpisuje się w nurt herstorii, mikrohistorii w kobiecym wydaniu. „Pamięć historyczna” jednostki, nacechowana płciowo, pozostaje $\mathrm{w}$ sprzeczności $\mathrm{z}$ oficjalnym przekazem zdominowanym przez kod patriarchalny. Punktem wyjścia dla refleksji bośniackiej pisarki jest odkrycie, że kobiety są pozbawione genealogii, po ich istnieniu nie zostaje żaden ślad: „Mi smo žene bez rodoslova, od nas i psi imaju dužu listu predaka" (Stupar Trifunović 2016: 65), co ma swoje źródło w głęboko zakorzenionym myśleniu patriarchalnym, wykluczającym kobiety z doświadczenia historycznego, zwłaszcza w kontekście wojny; to właśnie one i dzieci są wielkimi przegranymi i ofiarami w czasie wszelkich konfliktów zbrojnych (Aleksijewicz 2013, Aleksijewicz 2015). Narratorka wychodzi poza ścisłe ramy opowieści o własnej rodzinie i przeszłości, dokonuje pewnych uogólnień i spostrzeżenia dotyczące własnej rodziny przekształca w refleksje o charakterze uniwersalnym, opisujące doświadczenia ogólnoludzkie. Taki punkt widzenia znajduje odzwierciedlenie w konstrukcji powieści: jest to wielogłosowa powieść-mozaika, adekwatnym do sytuacji wyborem jest kompozycja otwarta, w której linearność początku i końca zostaje zdestabilizowana. Zliryzowany styl i poszarpana składnia oddają chaotyczność myśli i ambiwalencję uczuć kobiecych bohaterek.

Choć w utworze dominuje poczucie kobiecej wspólnoty, to jednak narratorka dokonuje w nim swego rodzaju rozrachunku z własną przeszłością, którego fabularnym uzasadnieniem jest motyw powrotu do rodzinnego domu, która to przestrzeń, będąca nośnikiem tożsamości, budzi emocjonalną ambiwalencję. Tok opowiadania jest podporządkowany rytmowi pamięci narratorki, a w mnogości głosów kobiet to głos matki jest tym najbardziej wyrazistym, jej głos jest także „wdrukowany” w umysł narratorki.

W centrum uwagi pozostaje relacja matka-córka i córka-matka, ukazana z dwóch perspektyw: macierzyństwa i córectwa ${ }^{5}$. Jest to możliwe dzięki wprowadzeniu do utworu trójpokoleniowej kobiecej wspólnoty reprezentowanej przez narratorkę, jej (nieżyjącą) matkę oraz córkę 
i niewątpliwie służy dowartościowaniu kobiecego doświadczenia. Narratorka wielokrotnie podkreśla ważność, wyjątkowość, ale i towarzyszące tej więzi ambiwalencje.

Pamięć autobiograficzna narratorki osadzona jest w czasie (dzieciństwo, młodość) oraz w przestrzeni (dom matki, zwłaszcza jej pokój oraz ogród), a bohaterka-narratorka ma poczucie rozdarcia i wykorzenienia: „Ipak sam ja dijete sa koferima, beskućnik, potucalo, bezemljaš, neko koga je vlastita zemlja abortirala je i poslala da se rodi negdje drugdje" (Stupar Trifunović 2016: 287) oraz rozdwojenia, co buduje jej tożsamość i poczucie nieprzynależenia do nikogo i do żadnego miejsca w pełni, na wyłączność. Źródło tej sytuacji ma swój początek w wojennej przeszłości. Prawdziwym i jedynym domem, zapewniającym autentyczne poczucie bezpieczeństwa okazuje się być literatura.

Podobnie w opowiadaniach Lejli Kalamujić z tomu Zovite me Esteban wojna pokazana jest jako łańcuch wydarzeń bezpowrotnie demolujących więzi międzyludzkie i nieodwracalnie burzących dotychczasowy ład. Choć - jak w utworze Od lokomotive do lokomotive - pojawiają się uwagi na temat konkretnych politycznych zmian, które zaszły w życiu mieszkańców byłej Jugosławii wraz z rozpadem państwa, to jednak dominuje aspekt emocjonalny: negacja bliskości między ludźmi, rozdzielanie rodzin, w efekcie czego pogłębia się pustka i poczucie opuszczenia/osamotnienia. Konsekwencją rozpadu ojczyzny dla narratorki jest stale już jej towarzyszące poczucie winy z powodu własnej nieobecności przy tych, którzy jej potrzebują, a śmierć kolejnych członków rodziny wzmacnia przekonanie o tym, że ich zdradziła. Poczucie winy mające swe źródło w przekonaniu, że zawiodła bliskich jest źródłem nienawiści do samej siebie: „Nisam bijesna. Ima već neko vrijeme da ne mrzim ljude oko sebe, samo sebe” (Kalamujić 2016: 17) i skutkuje poważnymi problemami psychicznymi.

W powojennym życiu literackim w Bośni i Hercegowinie aktywnie uczestniczą przedstawicielki wszystkich generacji, tworząc književnost razlika, na którą składa się szereg różnorodnych zjawisk literackich. Pod względem rodzajowym dominuje poezja oraz krótka proza, a elementem wspólnym, punktem odniesienia obecnym w utworach znakomitej większości Bośniaczek, bez względu na przynależność pokoleniową, jest trauma wojenna, z oczywistych przyczyn w tekstach młodszych autorek częściej obecna w formie niebezpośredniej, jako konsekwencje wojennych przeżyć. Znamienną cechą prezentowanej twórczości jest również nasycenie jej odniesieniami intertekstualnymi oraz refleksją autotematyczną, skupienie na zagadnieniach dotyczących relacji międzyludzkich, ze szczególnym uwzględnieniem związku matki i córki.

\section{TYPES OF FEMALE'S MEMORY OF THE WAR EXPERIENCE FIXED IN THE LITERATURE OF BOSNIA AND HERZEGOVINA}

SUMMARY The memory of the experience of the war in Bosnia and Herzegovina (1992-1995) is a phenomenon strongly present in contemporary literature. The subject of my interest is the specificity of women's memory, which is characterized primarily by anti-war and anti-military discourse, which is a fundamental feature of women's writing about the war, breaking the patriarchal code (statement by Swietlana Aleksijewicz). It should be noted that the work of authors writing in a traditional way functions in popular circulation, for which the 
ideology of war is significant, which is expressed e.g. in the presence of the figure of the Bosnian Mother, typical especially for literature on the experience of the genocide in Srebrenica (Nermina Kurspahić, Nura Bazdulj-Hubijar). A notable feature of women's creativity in $\mathrm{BiH}$ is that the memory of war is revealed in it in two fundamentally different ways:

1. a direct description of war experiences and experiences is usually visible in the texts of the authors of the older generation, whose writing, marked by the feature of autobiographism, reflects the civil experience of war, thus becoming part of the microhistory trend:

a) žensko ratno pismo (feminine writing about the war) (Alma Lazarevska), distinguished by the specific design of time and space, metaphorics wrapped around the house and body and narrative subordinated to the individual memory of the heroines. Representation of war experiences, often impossible to verbalize, is associated with the presence of body discourse;

b) a newly-novel women's novel (Jasmina Musabegović, Jasna Šamić) and drama (Nermina Kurspahić), in which the collective family memory stored by women is accompanied by a strong conviction of the repetition of the crime;

2. the indirect presence of the memory of the war in works whose subject matter and time of action is not directly related to the experience of war, but the war, in an unintended way, appears in the background of the story, is typical of the authors of the middle and younger generation (Šejla Šehabović, Lejla Kalamujić, Tanja Stupar-Trifunović), who declare their willingness to depart from the subject of war, but in practice it is impossible and the memory of war - both individual memory and, more often, family memory - turns out to be stronger.

\section{LITERATURA}

I A Biographical Dictionary of Women's Movements and Feminisms. Central, Eastern, and South Eastern Europe, 19th and 2oth Centuries, 2006, red. F. de Haan, K. Daskaloveji, A. Loutfi, Budapest-New York.

I Aleksijewicz S., 2013, Ostatni świadkowie. Utwory solowe na głos dziecięcy, przeł. J. Czech, Wołowiec.

I Aleksijewicz S., 2015, Wojna nie ma w sobie nic z kobiety, przeł. J. Czech, Wołowiec.

I Arsenijević D., 2012, Ljubav nakon genocida, http://sveske,ba/en/content/ljubav-nakongenocida. [data dostępu: 25.03.2017]

I Arsenijević D., 2017, Odrodzić płeć kości: polityka pamięci w Bośni i Hercegowinie, przeł. M. Koch i K. Taczyńska, „Teksty Drugie”, nr 2, s. 301-317.

I Bringa T., 2009, Biti Musliman na bosanski način. Identitet i zajednica u jednom srednjobosanskom selu, tłum. S. Krešo, Sarajevo-Zagreb, Dani Sarajevo.

I Czapik Lityńska B., 2009, „Uwikłane w przemoc”. Žensko pismo - dyskurs emancypacyjny i krytyczny z perspektywy teorii postkolonialnej, „Porównania”, nr 9, s. 165-177.

I Domańska E., 1999, Mikrohistorie. Spotkania w międzyświatach, Poznań.

I Drakulić S., 2010, Kao da me nema, Zagreb.

I Đurić D., 2011, Feministički i ženski časopisi u postjugoslovenskom kulturama, „ProFemina", specijalni broj leto/jesen, s. 263-282. 
I Erll A., Kultura pamięci. Wprowadzenie, przeł. A. Teperek, posłowie i red. M. Saryusz-Wolska, Warszawa.

I Felman S., 2004, Nauczanie i kryzys albo meandry edukacji, przeł. M. Lachman, „Literatura na Świecie", nr 1-2, s. 343-399.

I Hajdarewicz I., 2012, Bezdomne we wtasnym ciele - sytuacja kobiet w czasie wojny na Batkanach, http://krytyka.org/bezdomne-we-wlasnym-ciele-sytuacja-kobiet-w-czasie-wojny-na-balkanach/. [data dostępu: 11. 10. 2012]

I Hawkesworth C., 2000, Voices in the Shadows. Women and Verbal Art in Serbia and Bosnia, Budapest, New York.

I Husanović J., 2010, Između traume, imaginacije i nade. Kritički ogledi o kulturnoj produkciji iemancipativnoj politici, Beograd.

I Humm M., 1993, Stownik teorii feminizmu, przeł. B. Umińska i J. Mikos, Warszawa.

I Iwasiów I., 2006, Centralna płeć cywila. Wojna. Doświadczenie i zapis. Nowe źródta, problemy, metody badawcze, red. S. Buryła, P. Rodak, Kraków, s. 399-415.

I Iwasiów I., 2008, Gender dla średnio zaawansowanych. Wykłady szczecinskie, Warszawa.

I Jawoszek A., 2014, Boszniacy. Literackie narracje tożsamościowe po 1992 roku, Poznań.

I Kalamujić L., 2016, Zovite me Esteban, Beograd.

I Koji su pisci preživjeli raspad Jugoslavije?, 2013, „Peščanik”, http://pescanik.net/koji-supisci-preziveli-raspad-jugoslavije/print. [data dostępu: 15.06.2015]

I Kazaz E., 2004a, Bošnjački roman XX. vijeka, Zagreb-Sarajevo.

I Kazaz E., 2004b, Prizori uhodanog užasa, „Sarajevske Sveske”, br. 05, http://www.sveske.ba/ bs/content/prizori-uhodanog-uzasa. [data dostępu: 25.08.2011]

I Kazaz E., 2011, Politika svjedočenja i otpora. Antiratno pismo i društveno pamćenje u $\mathrm{BiH}$ nakon rata 1991-1995. Kultura sjećanja: 1991. Povijesni lomovi i svladavanje prošlosti, uredio Tihomir Cipek, Zagreb, s. 327-342.

I Keegan J., 1998, Historia wojen, z ang. przeł. G. Woźniak, Warszawa.

I Koch M., 2011, Ikony serbskiego romantyzmu jako bohaterowie współczesnej literatury popularnej, „Poznańskie Studia Slawistyczne”, nr 1, s. 127-144.

I Kowalczyk I., 2010, Matki-Polki, Chłopcy i Cyborgi... Sztuka i feminizm w Polsce, Poznań.

I Kraskowska E., 2005, Dyskurs feministyczny w słowiańskiej literaturze, krytyce i teorii po roku 1989. Literatury stowiańskie po roku 1989. Nowe zjawiska, tendencje, perspektywy, red. E. Kraskowska, t. II: Feminizm, Warszawa, s. 9-25.

I Lukić J., 2003, Žensko pisanje i žensko pismo u devedesetim godinama, „Sarajevske Sveske”, br. 02, http://www.sveske.ba/bs/content/zensko-pisanje-i-zensko-pismo-u-devedesetimgodinama. [data dostępu: 20.07.2011]

I Moranjak-Bamburać N., 2005, Nevolje s kanonizacijom, „Sarajevske Sveske”, br. 8-9, http://www.sveske.ba/bs/content/nevolje-s-kanonizacijom. [data dostępu: 13.02.2013]

I Mostov J., 1995, „Our women"/,their women”: symbolic boundaries, territorial markers and violence in the Balkans, „ProFemina”, br. 3, s. 210-217.

I Omeragić M., 2013, Da li je moguća de/balkanizacija rodova? Kažnjene progovaraju, „Sarajevske sveske”, br. 41-42, http://www.sveske.ba/bs/print/2643. [data dostępu: 08.07.2016]

I Pejković A., 2008, Rat, red i rod u zbirci priča Priče - ženski rod, množina Šejle Šehabović, „Sarajevske sveske”, 19-20, http://www.sveske.ba/bs/content/rat-red-i-rod-u-zbirci-pricaprice-\%E2\%80\%93-zenski-rod-mnozina-sejle-sehabovic. [data dostępu: 17. 09. 2016]

I Slapšak S., 2005, Feminizm i pisarstwo kobiet na polu minowym: paradygmat jugosłowiański i postjugosłowiański w perspektywie synchronicznej i diachronicznej, 
przeł. E. Kraskowska. Literatury stowiańskie po roku 1989. Nowe zjawiska, tendencje, perspektywy, red. E. Kraskowska, tom II: Feminizm, Warszawa, s. 137-168.

I Stevanović L., 2011, Žene kroz istoriju balkanskog patrijarhata, „ProFemina”, specijalni broj zima/proleće, s. 123-129.

I Šehabović Š., 2007, Priče - ženski rod, množina, Banjaluka.

I Sztompka P., 2000, Trauma wielkiej zmiany. Spoleczne koszty transformacji, Warszawa.

I Stupar Trifunović T., 2016, Satovi u majčinoj sobi, Sarajevo.

I Ubertowska A., 2014, Holokaust. (Auto)tanatografie, Warszawa.

I Ubertowska A., 2015, Kobiety i historia, Od niewidzialności do sprawczości. Kobiety i historia. Od niewidzialności do sprawczości, red. K. Bałżewska, D. Korczyńska-Partyka, A. Wódkowska, Gdańsk.

I Zabilježene. Žene i javni život u Bosni i Hercegovini u 20. vijeku, 2014, red. J. Čaušević, Sarajevo. 